\title{
molecules
}

ISSN 1420-3049

www.mdpi.com/journal/molecules

Article

\section{Synthesis, Spectroscopic and Theoretical Studies of New Dimeric Quaternary Alkylammonium Conjugates of Sterols}

\author{
Bogumił Brycki *, Hanna Koenig, Iwona Kowalczyk and Tomasz Pospieszny * \\ Laboratory of Microbiocide Chemistry, Faculty of Chemistry, Adam Mickiewicz University, \\ Grunwaldzka 6, Poznań 60-780, Poland; E-Mails: koenig@amu.edu.pl (H.K.); iwkow@amu.edu.pl (I.K.) \\ * Authors to whom correspondence should be addressed; E-Mails: brycki@amu.edu.pl (B.B.); \\ tposp@amu.edu.pl (T.P.); Tel.: +48-61-829-13-14 (B.B.); +48-61-829-13-07 (T.P.).
}

Received: 10 June 2014; in revised form: 30 June 2014 / Accepted: 1 July 2014 /

Published: 3 July 2014

\begin{abstract}
New dimeric quaternary alkylammonium conjugates of sterols were obtained by two step reactions of ergosterol, cholesterol and cholestanol with bromoacetic acid bromide, followed by bimolecular nucleophilic substitution with $N, N, N^{\prime}, N^{\prime}$-tetramethyl1,3-propanediamine, $N, N, N^{\prime}, N^{\prime \prime}, N^{\prime \prime}$-pentamethyldiethylenetriamine and 3,3'-iminobis( $N, N$-dimethylpropylamine). The product structures were confirmed by spectral $\left({ }^{1} \mathrm{H}-\mathrm{NMR}\right.$, ${ }^{13}$ C-NMR, FT-IR) analysis, mass spectrometry (ESI-MS) and PM5 semiempirical methods. Additionally in silico studies have been conducted for the synthesized compounds on the basis of Prediction of Activity Spectra for Substances (PASS).
\end{abstract}

Keywords: sterols; dimeric quaternary alkylammonium salt; conjugates; prediction of activity spectra for substances; quantum chemical calculations

\section{Introduction}

Steroids are very important natural products which play a crucial role in living organisms. This class of compounds comprises hormones, bile acids, steroidal saponins, cardioactive glycosides, steroid alkaloids and sterols [1-3]. One of the most important group among steroids are sterols, which can be divided into three groups: (1) zoosterols - the animal sterols (e.g., cholesterol, coprosterol); (2) phytosterols - the plant or algae sterols (e.g., sitosterol, stigmasterol); and (3) mycosterols - the sterols found in fungi (e.g., ergosterol, fungisterol) [4-6]. These compounds are crystalline secondary alcohols. Depending on the orientation of the condensed A and B rings of the steroid skeleton we can 
can distinguished between normal and allo sterols. In the first of them the A/B rings have a cis orientation, while the second have in trans geometry. Furthermore, all representative sterols have a $3 \beta$-hydroxyl group in ring A, endocyclic double bonds, usually located in the $\mathrm{C}(5)=\mathrm{C}(6)$ position and side chains which various degrees of unsaturation and branching $[7,8]$.

In fungi and animal cells, lanosterol originated from squalene is converted into ergosterol and cholesterol. On the other hand, cycloartenol serves a similar function in algae and plant cells (Scheme 1) [2-9].

Scheme 1. The biochemical transformations of cycloartenol and lanosterol to sterols.

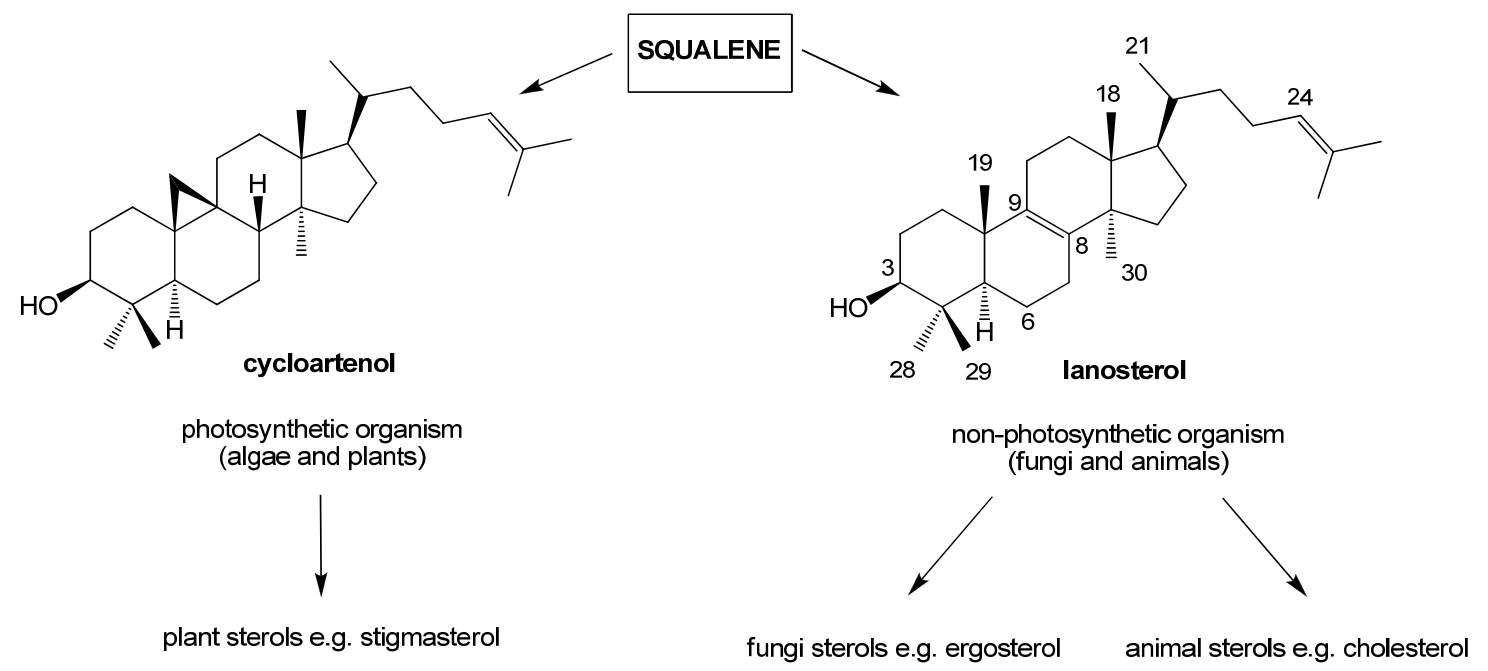

Among sterols, three of them are ubiquitous, i.e., ergosterol (1), cholesterol (2) and cholestanol (3), which is a metabolite of cholesterol (Scheme 2). Ergosterol is a vital sterol for fungal survival. It serves two purposes: a bulk membrane function and a sparking function [1,2,7,10]. Since ergosterol is part of the fungal cell membrane, fulfilling the same function as cholesterol (2) in animal cells, it is a target for antifungal drugs. Furthermore ergosterol is also a biological precursor to vitamin $\mathrm{D}_{2}[8,9,11,12]$.

An extremely important and well-known sterol is cholesterol. This sterol is an important component of mammalian cell membranes as in the ester form it stabilizes and stiffens protein-lipid membranes. Cholesterol is also present in significant concentrations in the brain and nervous tissue [13,14]. This animal sterol is the biosynthetic precursor of the steroid hormones, bile acids, vitamin D and lipoproteins [15-18]. On the other hand, gemini alkylammonium salts represent a new class of dimeric surfactants made up of two identical or different amphiphilic moieties having a monomeric quaternary alkylammonium salt connected by a linker (spacer) group structure [19,20]. The linker may be hydrophobic (aliphatic or aromatic) or hydrophilic (polyether, hydroxyalkyl). It can be rigid (stilbene) or flexible (a polymethylene chain). The gemini molecules have a neutral charge which is associated with the positive charge neutralization by negative ions such as e.g., halide anions [19-24]. The gemini alkylammonium salts show unique micelle-forming and surface-adsorbing properties in aqueous solution. The critical micelle concentration (CMC) for gemini surfactants is usually two orders lower than for corresponding monomeric surfactants [19,20,24-29]. The gemini alkylammonium compounds show also a very good antimicrobial activity against bacteria, viruses, molds and yeasts [30,31]. In some cases, the minimal inhibitory concentrations (MIC) of the discussed compounds are even three 
orders of magnitude lower in comparison to non-gemini connections [25,32,33]. The mechanism of biocidal activity of quaternary alkylammonium salts is based on adsorption of alkylammonium cations on the bacterial cell surface, diffusion through the cell wall and then binding and disruption of cytoplasmatic membrane. Membrane damage results in a release of potassium ions and other cytoplasmatic constituents, finally leading to cell death [25,34,35]. Frequently use of microbiocides, especially at sublethal concentrations, can lead to increasing microorganism resistance. One of the ways to overcome this serious negative side effect is the periodic application of new microbiocides with modified structures.

Scheme 2. Synthesis of dimeric quaternary alkylammonium conjugates 4-12 of sterols 1-3.

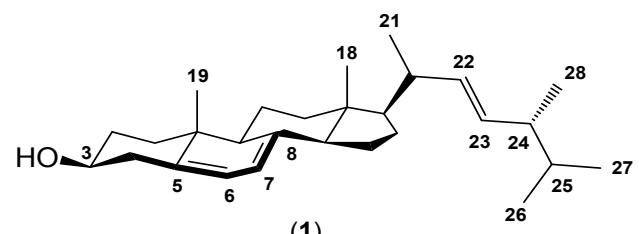

(1)

26
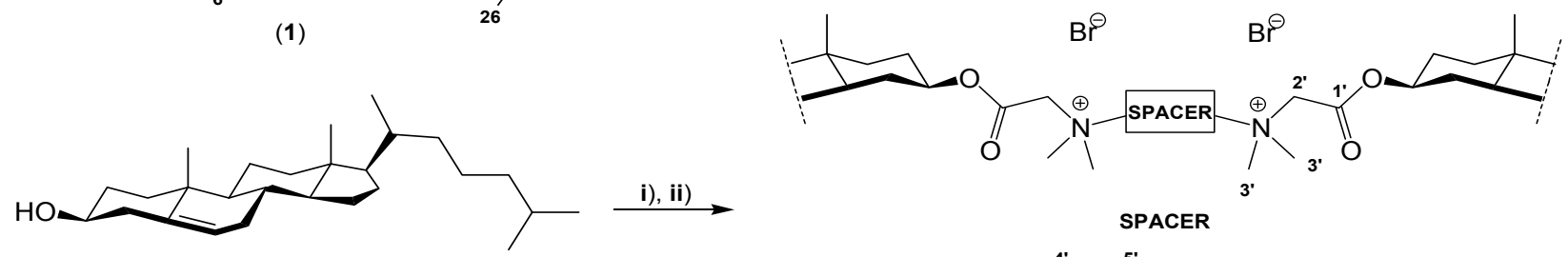

(2)

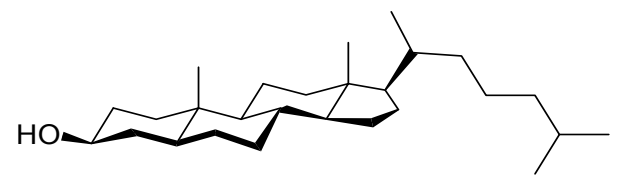

(3)

(4) $-4^{4} \mathrm{CH}_{2}-{ }^{5} \mathrm{CH}_{2}-\mathrm{CH}_{2-}$

(5) $-{ }^{4} \mathrm{CH}_{2}-{ }^{5} \mathrm{CH}_{2}-\mathrm{N}^{6}\left(\mathrm{CH}_{3}\right)-\mathrm{CH}_{2}-\mathrm{CH}_{2}-$

(6) $-{ }^{4} \mathrm{CH}_{2}{ }^{-5} \mathrm{CH}_{2}{ }^{7} \mathrm{CH}_{2}-\mathrm{NH}_{-} \mathrm{CH}_{2}-\mathrm{CH}_{2}-\mathrm{CH}_{2}$

(7) $-\mathrm{CH}_{2}-\mathrm{CH}_{2}-\mathrm{CH}_{2}-$

(8) $-\mathrm{CH}_{2}-\mathrm{CH}_{2}-\mathrm{N}\left(\mathrm{CH}_{3}\right)-\mathrm{CH}_{2}-\mathrm{CH}_{2}-$

(9) $-\mathrm{CH}_{2}-\mathrm{CH}_{2}-\mathrm{CH}_{2}-\mathrm{NH}-\mathrm{CH}_{2}-\mathrm{CH}_{2}-\mathrm{CH}_{2}-$

(10) $-\mathrm{CH}_{2}-\mathrm{CH}_{2}-\mathrm{CH}_{2}^{-}$

(11) $-\mathrm{CH}_{2}-\mathrm{CH}_{2}-\mathrm{N}\left(\mathrm{CH}_{3}\right)-\mathrm{CH}_{2}-\mathrm{CH}_{2}-$

(12) $-\mathrm{CH}_{2}-\mathrm{CH}_{2}-\mathrm{CH}_{2}-\mathrm{NH}-\mathrm{CH}_{2}-\mathrm{CH}_{2}-\mathrm{CH}_{2}-$

Reagents and conditions: i) $\mathrm{BrCH}_{2} \mathrm{COBr}$, TEBA, $\mathrm{CaH}_{2}, \mathrm{PhCH}_{3}$; ii) $N, N, N^{\prime}, N^{\prime}$-tetramethyl-1,3-propanediamine, $\left[N, N, N^{\prime}, N^{\prime \prime}, N^{\prime \prime}\right.$-pentamethyldiethylenetriamine or 3,3'-iminobis $(N, N$,-dimethylpropylamine $\left.)\right], \mathrm{CH}_{3} \mathrm{CN}, 81^{\circ} \mathrm{C}$.

Potential pharmacological activities of the synthesized compounds have been found on the basis of computer-aided drug discovery approach with in silico of the successful use of the PASS approach leading to new pharmacological agents [36-40]. Through the use of PASS the biological activity of the obtained compounds may be analyzed. This approach can be used at the earliest stages of investigation, because only the structural formula of the compound is necessary to obtain a PASS prediction.

\section{Results and Discussion}

However, to the best of our knowledge, no work has been published on the synthesis and physicochemical properties of dimeric quaternary alkylammonium conjugates of sterols. These new conjugates were obtained by reaction of sterols (ergosterol (1), cholesterol (2), cholestanol (3)) with bromoacetic acid bromide to give ergosteryl $3 \beta$-bromoacetate, cholesteryl $3 \beta$-bromoacetate and dihydrocholesteryl $3 \beta$-bromoacetate $[41,42]$.

The bromoacetates were the subjected to reactions with $N, N, N^{\prime}, N^{\prime}$-tetramethyl-1,3-propanediamine, $N, N, N^{\prime}, N^{\prime \prime}, N^{\prime \prime}$-pentamethyldiethylenetriamine and 3,3'-iminobis( $N, N$-dimethylpropylamine). Reactions 
were carried out in acetonitrile at reflux for different times. These conditions favor bimolecular nucleophilic substitution, and optimize the reaction yields. The syntheses of dimeric conjugates 4-12 are shown in Scheme 2.

The structures of all synthesized compounds were determined by ${ }^{1} \mathrm{H}-$ and ${ }^{13} \mathrm{C}-\mathrm{NMR}$, FT-IR and ESI-MS spectra. Moreover, PM5 calculations [43-45] were performed for all compounds. Additionally the pharmacotherapeutic potential of the synthesized compounds has been estimated on the basis of Prediction of Activity Spectra for Substances (PASS).

Figure 1. ${ }^{1} \mathrm{H}-\mathrm{NMR}$ spectra in the $5.5-2.5 \mathrm{ppm}$ region showing the most characteristic signals of conjugates 4 (a); 7 (b); and 10 (c).

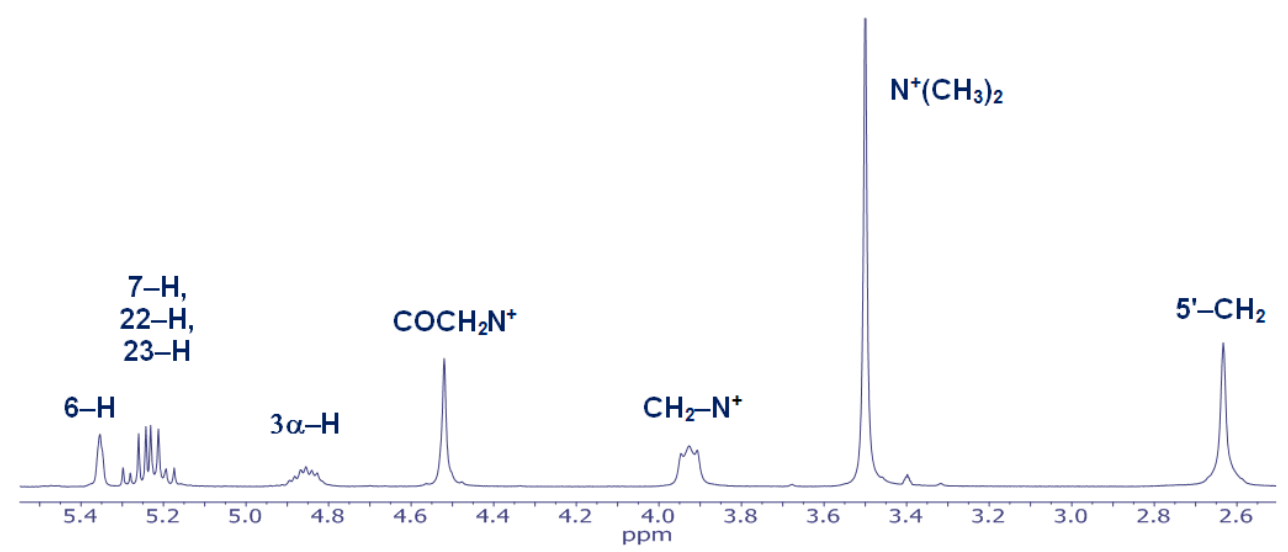

(a)

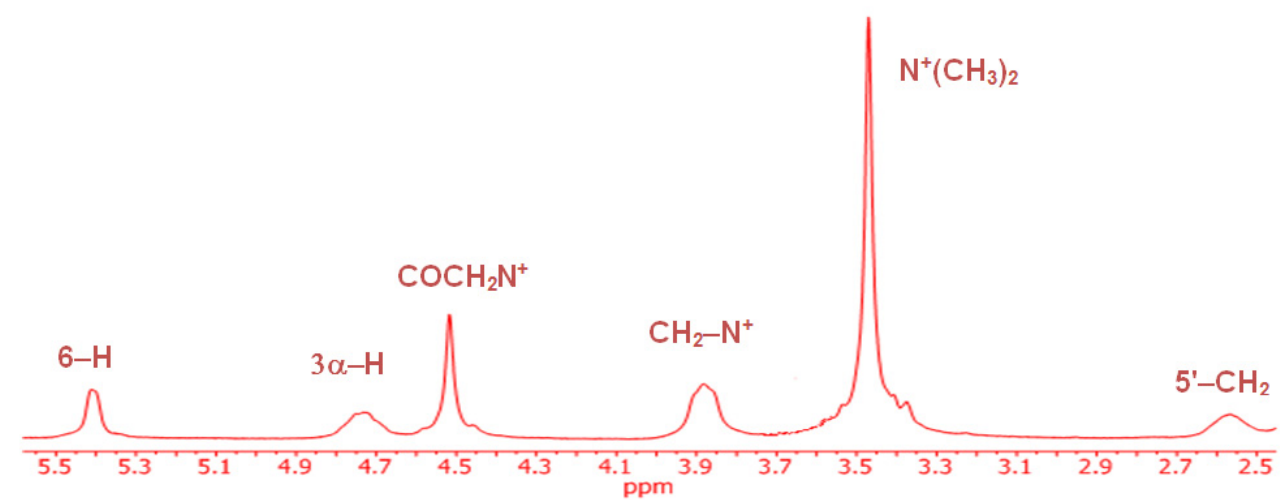

(b)

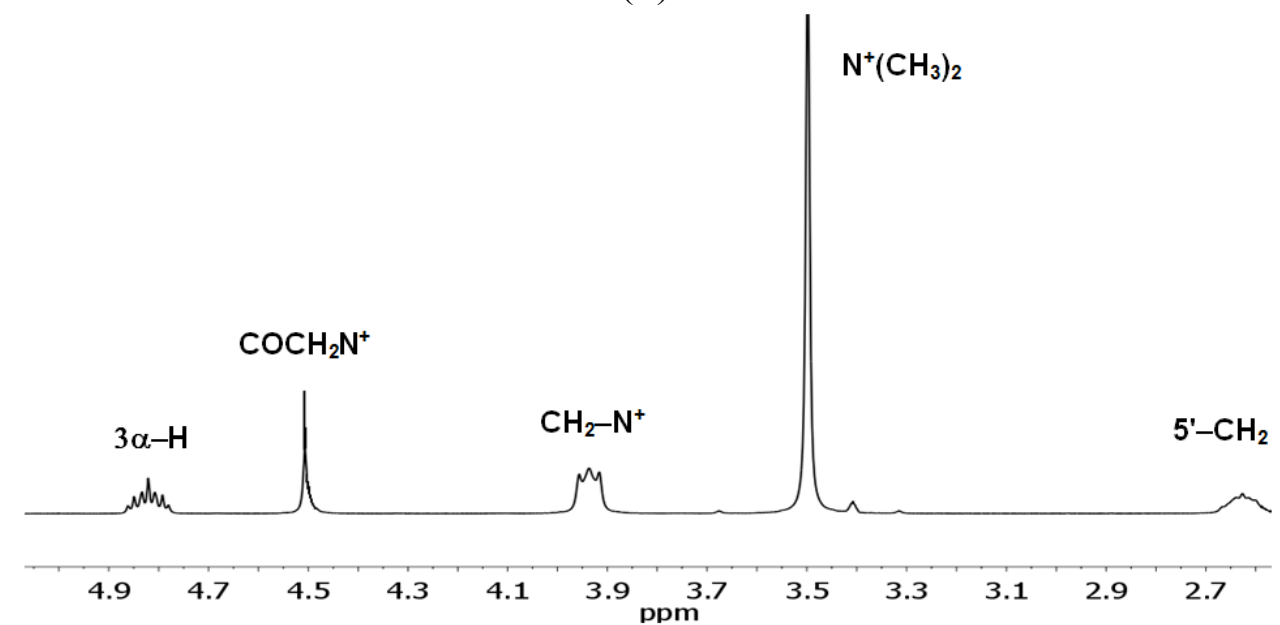

(c) 
The ${ }^{1} \mathrm{H}$ - and ${ }^{13} \mathrm{C}$-NMR data spectra were assigned on the basis of our previous study [41,42]. The ${ }^{1} \mathrm{H}-\mathrm{NMR}$ spectra of 4-12 show a signal in the range 4.65-4.48 ppm for the protons of the $\mathrm{COCH}_{2} \mathrm{~N}^{+}$ group. The signals for six methyl protons of the $\mathrm{N}^{+}\left(\mathrm{CH}_{3}\right)_{2}$ and two methylene protons of the $\mathrm{N}^{+} \mathrm{CH}_{2}$ occurred as singlets and triplets in the 3.58-3.46 and 4.44-3.89 ppm range, respectively (Figure 1).

The ${ }^{1} \mathrm{H}-\mathrm{NMR}$ spectra of compounds 4-12 show characteristic multiplets in the 4.92-4.61 ppm range assigned to the $\mathrm{C} 3 \alpha-\mathrm{H}$ protons of the sterol skeleton. Characteristic hydrogen singlets ranging from 0.69-0.65 ppm for 7-9 and 10-12 are assigned to $\mathrm{CH}_{3}-18$. Moreover, very characteristic triplets appear in the $0.84 \mathrm{ppm}$ region for $\mathrm{CH}_{3}-18$ and $\mathrm{CH}_{3}-26$ as well as $\mathrm{CH}_{3}-27$ of the ergosterol substituted derivatives 4-6. Ergosterol derivatives show multiplets in the 5.30-5.16 ppm range assigned to H-7, $\mathrm{H}-22$ as well as $\mathrm{H}-23$ protons. The second sets of singlets ranging from 1.03-0.82 ppm were assigned to $\mathrm{CH}_{3}-19$ for all compounds. The characteristic doublets of $\mathrm{CH}_{3}-21$ are $0.93-0.90$ in dimeric conjugates. The ${ }^{1} \mathrm{H}-\mathrm{NMR}$ spectra of 7-12 show a doublet of doublets at $0.87-0.86 \mathrm{ppm}$ for the protons of the $\mathrm{C}(26)$ and $\mathrm{C}(27)$ methyl groups. For compounds 4-6 a doublet appears in the $1.04 \mathrm{ppm}$ assigned to $\mathrm{CH}_{3}-28$. The ${ }^{1} \mathrm{H}-\mathrm{NMR}$ spectra of compounds 4, 7, 10 show triplets in the 2.64-2.54 ppm range assigned to the $\mathrm{N}-\mathrm{CH}_{2}-$ protons of the propylene spacer. On the other hand, methylene protons of $\mathrm{N}\left(\mathrm{CH}_{3}\right)-\mathrm{CH}_{2}-$ for 5, 8, 11 and $\mathrm{NH}-\mathrm{CH}_{2}-$ for 6, 9, 12 appear in the range of 3.13-3.10 and 2.95-2.90 ppm, respectively. The signals for three methyl protons of the $\mathrm{N}-\mathrm{CH}_{3}$ appear as singlets in the $2.38-2.35$ ppm range.

The ${ }^{13} \mathrm{C}-\mathrm{NMR}$ spectra of compounds 4-12 are summarized in Table 1. The spectra show characteristic signals at 15.79-15.63 ppm (compounds 4-6) and 12.12-11.65 ppm (compounds 7-12), which are assigned to $\mathrm{CH}_{3}-18$. In a series of 10-12 derivatives the signals from the $\mathrm{CH}_{3}-18$ group carbon atoms from both steroid skeletons are observed (Table 2). The carbon atoms signal of the $\mathrm{CH}_{3}-19$ and $\mathrm{CH}_{3}-21$ groups appear in the 19.15-18.03 ppm and 21.13-18.50 ppm range, respectively. Furthermore, the $\mathrm{CH}_{3}-26 / 27$ groups are shown in the range of 22.59-22.47 ppm for 7-12 and 19.60-19.45 ppm for 4-6. On the other hand for compounds 4-6 a diagnostic signal of carbon atom of $\mathrm{CH}_{3}-28$ group is observed at $17.62-17.47 \mathrm{ppm}$. Two important signals for $\mathrm{C}\left(1^{\prime}\right)=\mathrm{O}$ and $\mathrm{C}(3)-\mathrm{O}$ were present at 164.07-163.57 ppm and 77.20-76.55 ppm, respectively. The spectra of all dimeric compounds show two diagnostic signals associated with the $\mathrm{CH}_{2}$ atoms in $\mathrm{N}^{+}-\mathrm{C}\left(2^{\prime}\right) \mathrm{H}_{2}-\mathrm{CO}$ and $\mathrm{N}^{+}-\mathrm{C}\left(4^{\prime}\right) \mathrm{H}_{2}$ groups. The carbon atoms in the first group are located at $65.61-61.49 \mathrm{ppm}$ and the second group at 62.24-61.48 ppm, respectively. It is noteworthy that for the $-\left(\mathrm{CH}_{2}\right)_{3}-$ linker (compounds 4, 7, 10) the carbons of the $\mathrm{CH}_{2}$ groups gave signals in the 62.71-62.07 ppm range. In turn, for the linker $\left[\left(\mathrm{CH}_{2}-\mathrm{CH}_{2}\right)_{2} \mathrm{NCH}_{3}\right]$ (compounds 5, 8, 11) they were at 61.91-61.49 ppm, and for the linker $\left[\left(\mathrm{CH}_{2}-\mathrm{CH}_{2}-\mathrm{CH}_{2}\right)_{2} \mathrm{NH}\right]$ (compounds 6, 9, 12) they were in 65.61-65.58 ppm. The $\mathrm{N}^{+}\left(\mathrm{CH}_{3}\right)_{2}$ carbon atoms resonate in the $52.21-50.81 \mathrm{ppm}$ range.

The solid-state IR spectra of representative conjugates 6, 9 and $\mathbf{1 2}$ are shown in Figure 2. The strong band in the $3,350-3,330 \mathrm{~cm}^{-1}$ region has been assigned to the $\mathrm{NH}$ group with no hydrogen bond to bromide anion. The intense bands in the $1,740-1,739 \mathrm{~cm}^{-1}$ region are due to the carbonyl group $v(\mathrm{C}=\mathrm{O})$ stretching vibrations (Figure 3). The presence of two strong band at 1,739 and $1,721 \mathrm{~cm}^{-1}$ for 12 indicates the non-equivalence of the carbonyl groups. The split of the carbonyl bands suggest that both carbonyl groups in $\mathbf{1 2}$ are involved in different interactions in the supramolecular structure. Further coupling has little or no effect on the carbonyl group vibration. Some more strong characteristic bands in the $1,248-1,227 \mathrm{~cm}^{-1}$ region are present, which are assigned to the $v(\mathrm{C}-\mathrm{O})$. The 
$v(\mathrm{C}=\mathrm{C})$ stretching vibration bands of compounds 6 and 9 occur at $1,665 \mathrm{~cm}^{-1}$ and $1,670 \mathrm{~cm}^{-1}$ respectively; for compound $\mathbf{1 2}$ this band is absent. The $\delta(\mathrm{N}-\mathrm{H})$ deformation vibration bands are observed at $1,629 \mathrm{~cm}^{-1}, 1,635 \mathrm{~cm}^{-1}, 1,634 \mathrm{~cm}^{-1}$ for $\mathbf{6 , 9}$ as well as 12, respectively (Figure 3).

Table 1. The ${ }^{13} \mathrm{C}-\mathrm{NMR}$ chemical shifts (ppm) of compounds 4-12.

\begin{tabular}{cccccccccc}
\hline Carbon & $\mathbf{4}$ & $\mathbf{5}$ & $\mathbf{6}$ & $\mathbf{7}$ & $\mathbf{8}$ & $\mathbf{9}$ & $\mathbf{1 0}$ & $\mathbf{1 1}$ & $\mathbf{1 2}$ \\
\hline $1^{\prime}$ & 163.70 & 163.89 & 164.07 & 163.57 & 163.75 & 163.95 & 163.59 & 163.87 & 163.99 \\
$2^{\prime}$ & 62.71 & 61.91 & 65.61 & 62.07 & 61.54 & 65.59 & 62.24 & 61.49 & 65.58 \\
$3^{\prime}$ & 51.58 & 52.15 & 50.82 & 51.72 & 52.18 & 50.81 & 51.49 & 52.21 & 50.82 \\
$4^{\prime}$ & 62.07 & 61.88 & 61.62 & 61.66 & 61.52 & 61.58 & 62.24 & 61.48 & 61.59 \\
$5^{\prime}$ & - & 56.92 & - & - & 55.96 & - & - & 54.02 & - \\
$6^{\prime}$ & - & 49.67 & - & - & 49.82 & - & - & 49.88 & - \\
$7^{\prime}$ & - & - & 57.01 & - & - & 56.60 & - & - & 54.02 \\
3 & 76.77 & 76.56 & 76.55 & 77.19 & 76.67 & 77.13 & 77.15 & 76.97 & 77.20 \\
5 & 139.75 & 139.73 & 139.87 & 138.56 & 138.55 & 138.74 & - & - & - \\
6 & 123.26 & 123.21 & 123.30 & 123.37 & 138.55 & 123.38 & - & - & - \\
7 & 118.08 & 118.02 & 118.11 & - & - & - & - & - & - \\
8 & 150.47 & 150.45 & 150.55 & - & - & - & - & - & - \\
18 & 15.68 & 15.63 & 15.79 & 11.65 & 11.66 & 11.77 & $11.86,11.96$ & $11.88,11.99$ & $11.92,12.12$ \\
19 & 18.08 & 18.03 & 18.23 & 18.99 & 19.01 & 19.15 & 18.45 & 18.48 & 18.58 \\
21 & 19.83 & 19.77 & 19.92 & 18.50 & 18.51 & 18.64 & 21.04 & 21.07 & 21.13 \\
22 & 135.33 & 135.30 & 135.42 & - & - & - & - & - & - \\
23 & 132.02 & 131.98 & 132.07 & - & - & - & - & - & - \\
$26 / 27$ & 19.51 & 19.45 & 19.60 & 22.56 & 22.59 & 22.47 & 22.57 & 22.58 & 22.47 \\
28 & 17.52 & 17.47 & 17.62 & - & - & - & - & - & - \\
\hline
\end{tabular}

Table 2. Heat of formation (HOF) [kcal/mol] of sterols (1-3) and their conjugates 4-12.

\begin{tabular}{|c|c|c|c|c|c|}
\hline Compound & $\begin{array}{c}\text { HOF } \\
{[\mathrm{kcal} / \mathrm{mol}]}\end{array}$ & $\begin{array}{c}\text { HOF } \\
\text { syn Conformer } \\
{[\mathrm{kcal} / \mathrm{mol}]} \\
\end{array}$ & $\begin{array}{c}\text { HOF } \\
\text { anti Conformer } \\
{[\mathrm{kcal} / \mathrm{mol}]}\end{array}$ & $\begin{array}{c}\Delta \mathrm{HOF}_{s y n} \\
{[\mathrm{kcal} / \mathrm{mol}]}\end{array}$ & $\begin{array}{c}\Delta \mathrm{HOF}_{a n t i} \\
{[\mathrm{kcal} / \mathrm{mol}]}\end{array}$ \\
\hline 1 & -97.1208 & - & - & - & - \\
\hline 2 & -140.1058 & - & - & - & - \\
\hline 3 & -162.7945 & - & - & - & - \\
\hline 4 & - & -262.2720 & -255.9961 & -165.1512 & $\begin{array}{c}-158.875 \\
3\end{array}$ \\
\hline 5 & - & -250.2337 & -250.1800 & -153.1129 & -153.0592 \\
\hline 6 & - & -276.4203 & -257.6516 & -179.2995 & -160.5308 \\
\hline 7 & - & -345.4121 & -341.1838 & -205.3063 & -201.0780 \\
\hline 8 & - & -338.9490 & -332.2815 & -198.8432 & -192.1757 \\
\hline 9 & - & -358.2366 & -342.9308 & -218.1308 & -202.8250 \\
\hline 10 & - & -393.0944 & -386.6933 & -230.2990 & -223.8988 \\
\hline 11 & - & -380.3771 & -377.8571 & -217.5826 & -215.0626 \\
\hline 12 & - & -407.2888 & -388.2125 & -244.4943 & -225.4180 \\
\hline
\end{tabular}

$\Delta \mathrm{HOF}_{\text {syn }}=\mathrm{HOF}_{\text {conjugates (4-12) }}-\mathrm{HOF}_{\text {sterols (1-3) }} ; \Delta \mathrm{HOF}_{\text {anti }}=\mathrm{HOF}_{\text {conjugates (4-12) }}-\mathrm{HOF}_{\text {sterols (1-3). }}$. 
Figure 2. FT-IR spectra of conjugates 6 (blue), 9 (red), 12 (black) in the 3,500-600 $\mathrm{cm}^{-1}$ region.

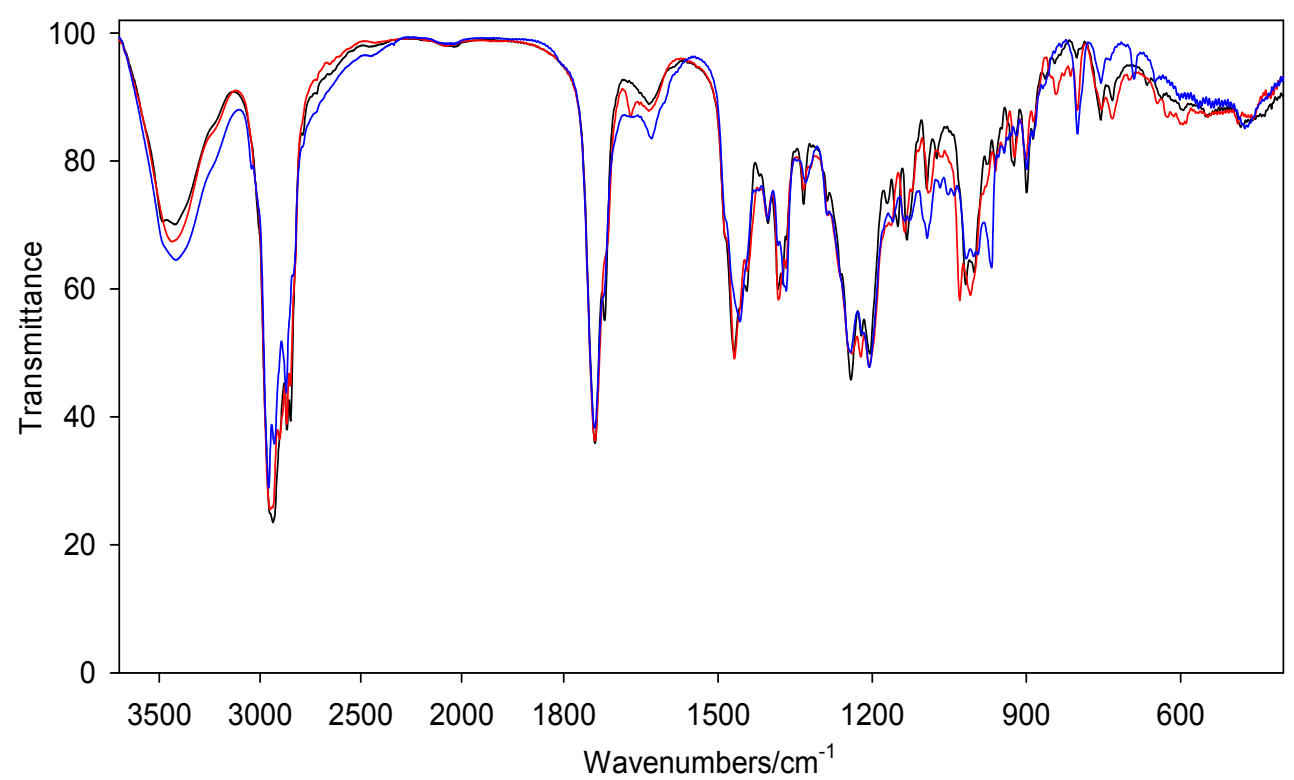

Figure 3. FT-IR spectra of sterol gemini conjugates in the $1,800-1,550 \mathrm{~cm}^{-1}$ region for 6 (blue), 9 (red), 12 (black).

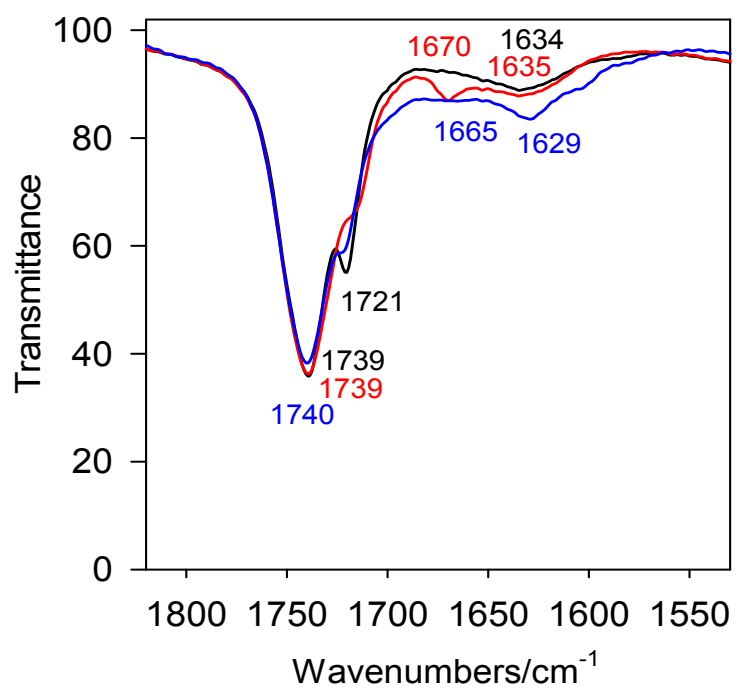

The ESI-MS spectra were recorded in methanol. The ESI-MS spectra of compounds $\mathbf{6 , 9}$ and $\mathbf{1 2}$ are presented in Figure 4. The ESI mass spectrometry fragmentation pathways of these compounds is poor. It is rather more diagnostic than analytical. The molecular ion $[\mathrm{M}]^{+}$is not observed. Furthermore, in the spectra of these compounds, the $[\mathrm{M}]^{2+}$ ion peaks are observed at $m / z 531(69 \%), 521(28 \%)$ as well as $523(23 \%)$ for $\mathbf{6}, 9$ and $\mathbf{1 2}$, respectively. In the discussed compounds, the presence of $\left[\mathrm{M}^{2+}+2 \mathrm{Br}^{-}+\text {amine }+2 \mathrm{H}^{+}+\mathrm{AcOEt}\right]^{2+}$ ions $(100 \%)$ was observed at $m / z 748,732$ and 741 for $\mathbf{6}, 9$ as well as 12, respectively. For all other compounds $(4,5,7,8,10,11)$ were seen ions $[\mathrm{M}]^{2+}$ and $\left[\mathrm{M}^{2+}+\mathrm{Br}^{-}\right]^{+}$. 
Figure 4. ESI-MS spectrum of compounds 6 (a); 9 (b); 12 (c).

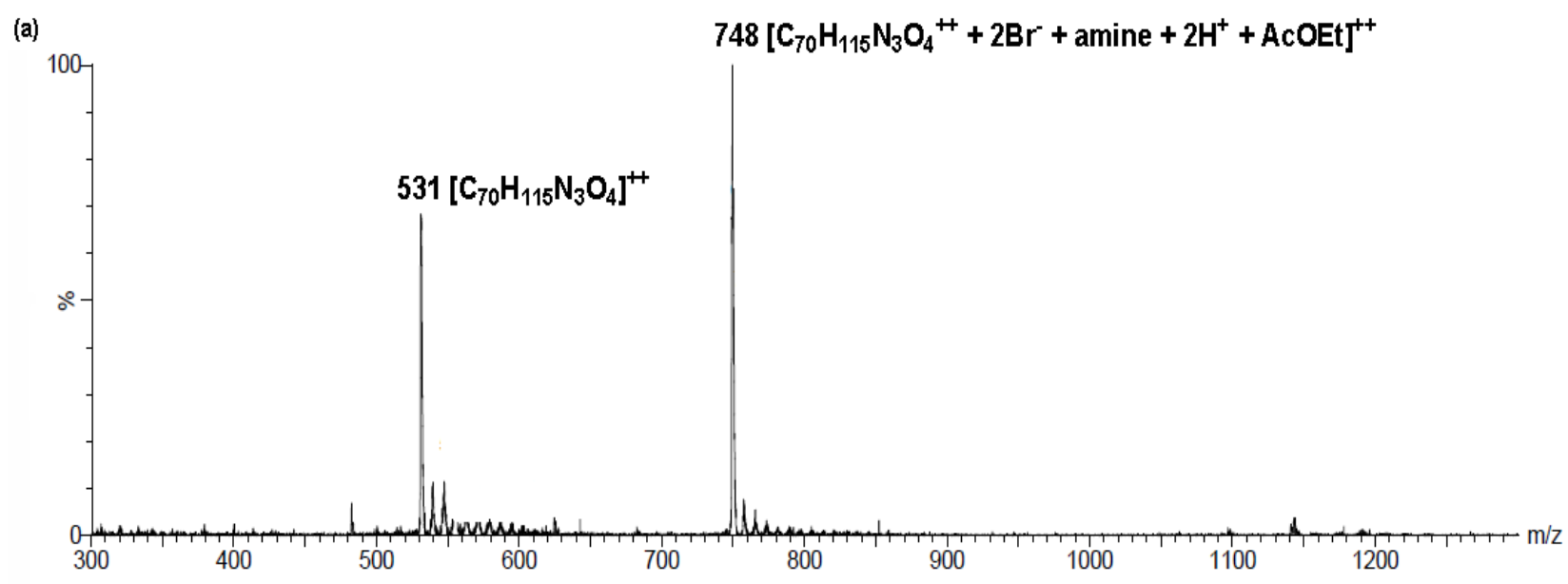

(a)

(b)

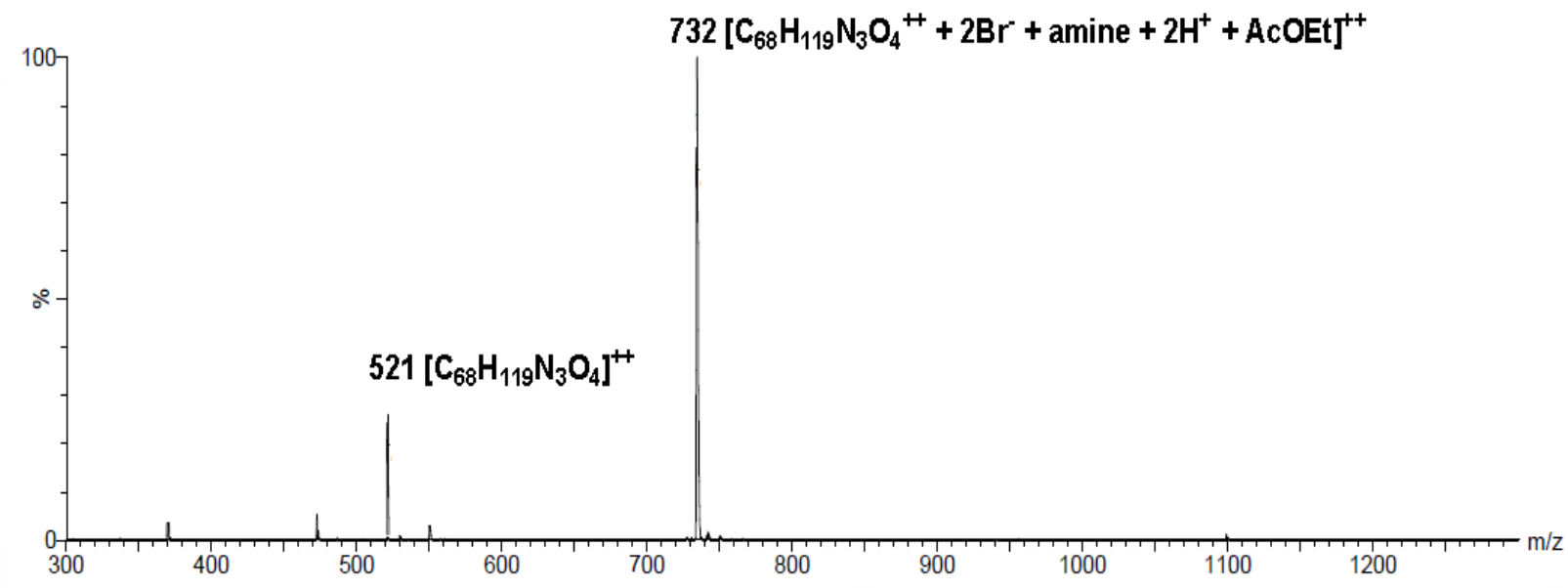

(b)

(c)

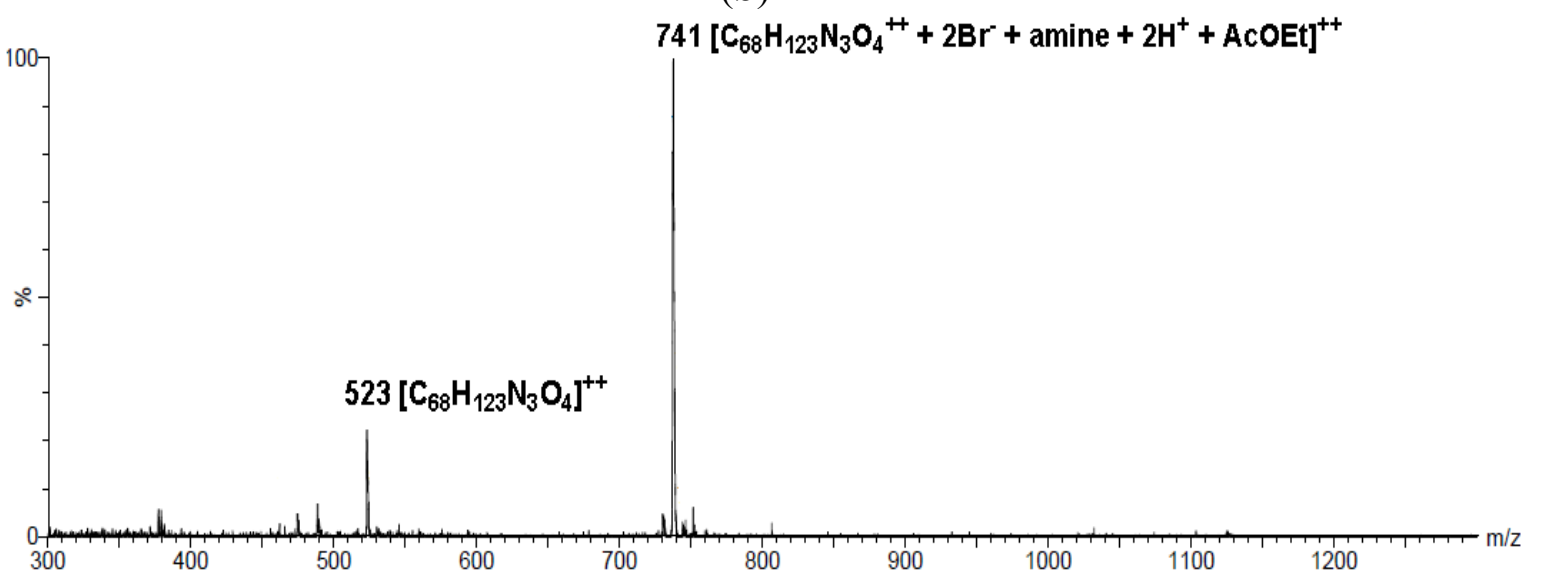

(c)

PM5 semiempirical calculations were performed using the WinMopac 2003 program [43-45]. The final heat of formation (HOF) for the sterols $\mathbf{1}-\mathbf{3}$ and conjugates 4-12 is presented in Table 2. Representative compounds 7, 8 and 9 are shown in Figure 5. 
Figure 5. The syn (a) and anti (b) conformers of compounds 7, 8 and 9 calculated by the PM5 method.

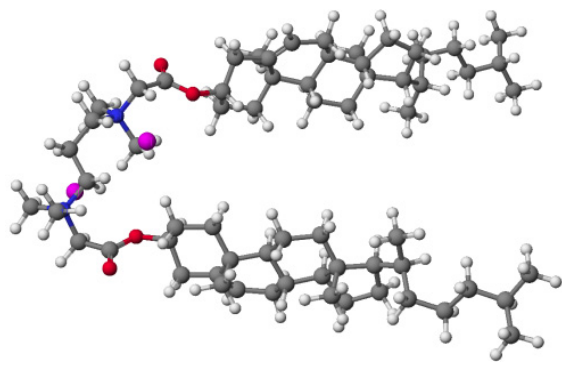

(7)

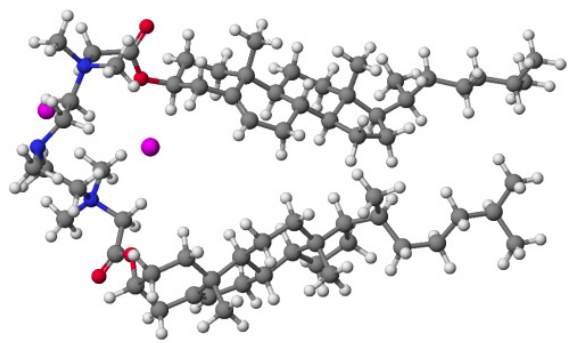

(8)

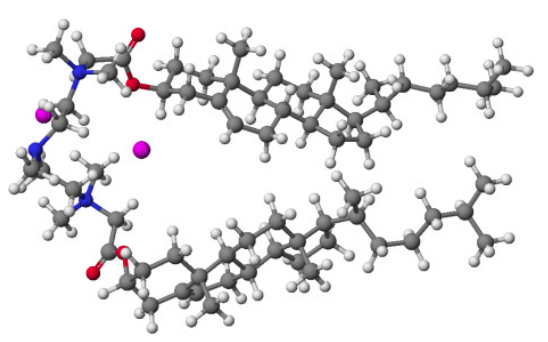

(9)

(a)

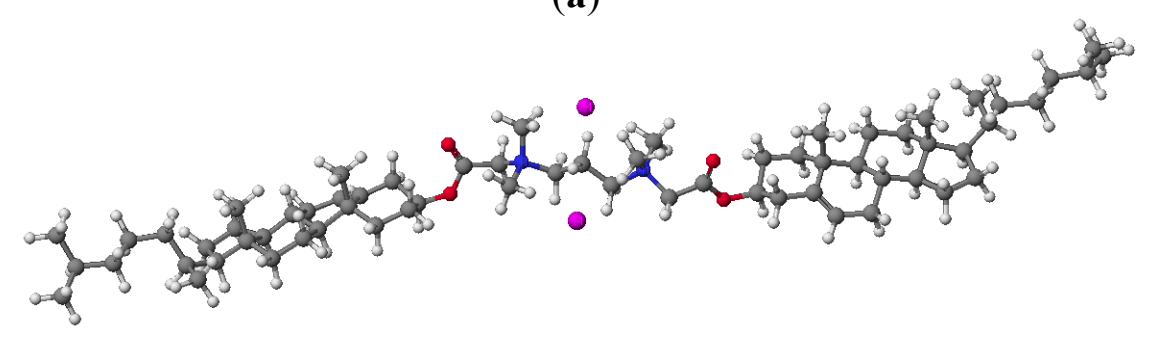

(7)

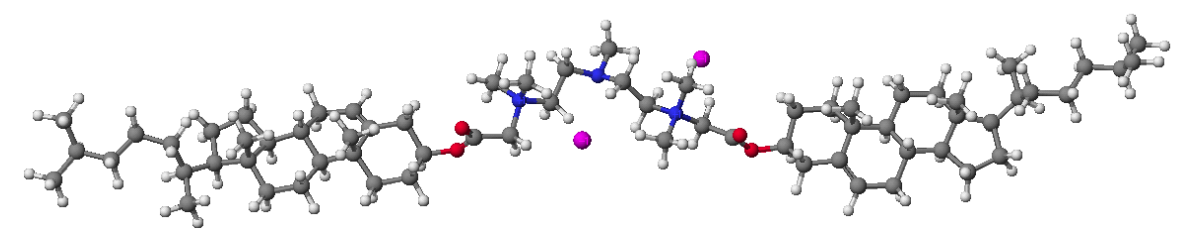

(8)

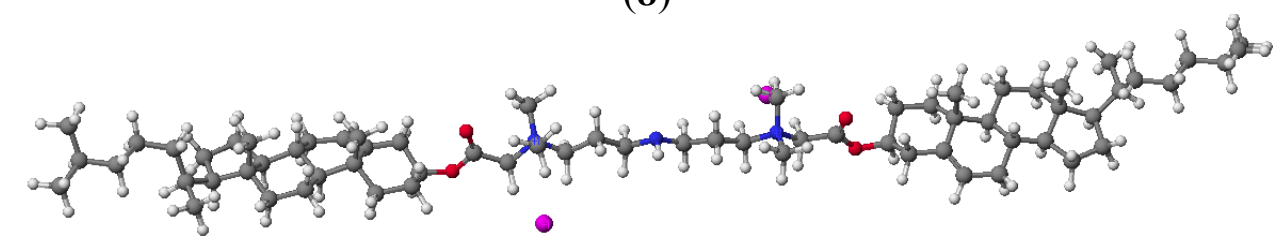

(9)

(b)

In ergosterol derivatives 4-6 and cholesterol ones 7-9 where double bonds are present increasing HOF values are observed. The lowest HOF value is observed for cholestanol and its derivatives 10-12 where there are no double bonds to stabilize the molecules and hinder their reactivity. Two low energy syn and anti conformers are possible for the dimeric-type quaternary alkylammonium conjugates of sterols as a consequence of the free rotation of bonds in the linker fragment. Semiempirical calculations on compounds 4-12 showed that the syn conformer was more stable than the anti conformer by $0.05-19.07 \mathrm{kcal} / \mathrm{mol}$. The distances between the quaternary nitrogen and the anion bromide are 3.70-4.66 $\AA$ for syn and 3.46-3.88 $\AA$ for anti conformers, respectively. The distances between the quaternary nitrogen atoms and the oxygen atoms are 2.89-3.35 $\AA$ for syn and 2.93-3.88 $\AA$ for anti conformers, respectively. Compensation charges occurs only through intramolecular electrostatic interaction. In optimized structures, the anion is not engaged in hydrogen bond but in electrostatic interactions what is also confirmed by FT-IR studies in the solid phase. The variations of dihedral angles reflects the flexibility of the $\mathrm{N}^{+} \mathrm{CH}_{2} \mathrm{COOR}$ moiety. The PM5 calculations indicate that the 
conformations of all molecules are controlled by the electrostatic interactions of the positively charged nitrogen atom with the oxygen atoms of the COOR moiety and bromide anions. This is a very good confirmation of the conclusion that interactions reduce HOF.

Additionally, analyses of the biological prediction activity spectra for the new esters prepared herein are good examples of in silico studies of chemical compounds. We also selected the types of activity that were predicted for a potential compound with the highest probability (focal activities) (Table 3).

Table 3. PA (Probability "to be Active") values for predicted biological activity of compounds 4-12.

\begin{tabular}{ccccccccccc}
\hline \multirow{2}{*}{ Focal Predicted Activity $(\mathbf{P A}>\mathbf{8 0})$} & \multicolumn{11}{c}{ Compounds } \\
\cline { 2 - 11 } & $\mathbf{4}$ & $\mathbf{5}$ & $\mathbf{6}$ & $\mathbf{7}$ & $\mathbf{8}$ & $\mathbf{9}$ & $\mathbf{1 0}$ & $\mathbf{1 1}$ & $\mathbf{1 2}$ \\
\hline Glyceryl-ether monooxygenase inhibitor & 89 & 89 & 88 & 92 & 92 & 91 & 95 & 95 & 94 \\
Cholesterol antagonist & 81 & 85 & - & 87 & 89 & 82 & 82 & 86 & - \\
Antihypercholesterolemic & 88 & 83 & 86 & 85 & 80 & 83 & - & 94 & - \\
Acylcarnitine hydrolase inhibitor & - & - & - & 85 & 80 & - & 96 & - & 93 \\
Oxidoreductase inhibitor & 87 & 86 & 85 & - & - & - & - & - & - \\
Alkylacetylglycerophosphatase inhibitor & - & - & - & - & - & - & 90 & 87 & 83 \\
Alkenylglycerophosphocholine hydrolase inhibitor & - & - & - & - & - & - & 88 & 82 & 80 \\
Alcohol $O$-acetyltransferase inhibitor & 91 & 90 & 90 & - & - & - & - & - & - \\
\hline
\end{tabular}

The most important parameter is the predicted activity (PA). PA $>0.7$ indicate a high probability of occurrence of a particular activity, which give a high chance to confirm it in real clinical tests. For most cases, PA $>0.7$ have a structure similar to the structure of the known drug substance. In turn, $50<\mathrm{PA}<70$, are compounds for which the probability of confirmation of biological activity in biological research is smaller. On the other hand PA $<0.5$ pertain to compounds for which the confirmation of biological activity in biological research is small, but this group connection may include new compounds structurally. We focused on the first compartment.

According to these data the most frequently predicted types of biological activity are: glyceryl-ether monooxygenase inhibitor, cholesterol antagonist as well as antihypercholesterolemic, respectively. The gemini quaternary alkylammonium conjugates 4-6 of ergosterol addition showed inhibition of oxidoreductase and alcohol $O$-acetyltransferase. On the other hand conjugates of 10-12 showed inhibition of alkylacetylglycerophosphatase and alkenylglycerophosphocholine hydrolase.

\section{Experimental Section}

\subsection{General Information}

The NMR spectra were measured with a Spectrometer NMR Varian Mercury $300 \mathrm{MHz}$ (Oxford, UK), operating at 300.07 and 75.4614 for ${ }^{1} \mathrm{H}$ and ${ }^{13} \mathrm{C}$, respectively. Typical conditions for the proton spectra were: pulse width $32^{\circ}$, acquisition time $5 \mathrm{~s}$, FT size $32 \mathrm{~K}$ and digital resolution $0.3 \mathrm{~Hz}$ per point, and for the carbon spectra pulse width $60^{\circ}$, FT size $60 \mathrm{~K}$ and digital resolution $0.6 \mathrm{~Hz}$ per point, the number of scans varied from 1200 to 10,000 per spectrum. The ${ }^{13} \mathrm{C}$ and ${ }^{1} \mathrm{H}$ chemical shifts were measured in $\mathrm{CDCl}_{3}$ with methanol relative to an internal standard of TMS. Infrared spectra were recorded in the $\mathrm{KBr}$ pellets using a FT-IR Bruker IFS 66 spectrometer (Karlsruhe, Germany). The ESI 
(electron spray ionization) mass spectra were recorded on a Waters/Micromass (Manchester, UK) ZQ mass spectrometer equipped with a Harvard Apparatus (Saint Laurent, QC, Canada), syringe pump. The sample solutions were prepared in methanol at the concentration of approximately $10^{-5} \mathrm{M}$. The standard ESI-MS mass spectra were recorded at the cone voltage $30 \mathrm{~V}$. The sterols and amines are the commercial products from Sigma-Aldrich (Saint Louis, MO, USA).

\subsection{Synthesis: General Procedure for the Synthesis of Quaternary Ammonium C Onjugates of Sterols}

Ergosteryl $3 \beta$-bromoacetate (cholesteryl $3 \beta$-bromoacetate or dihydrocholesteryl $3 \beta$-bromoacetate) (2.2 eq.) was dissolved in $\mathrm{CH}_{3} \mathrm{CN}$ (3 mL) under reflux. Then the appropriate amine $\left[N, N, N^{\prime}, N^{\prime}\right.$-tetramethyl-1,3-propanediamine, $\quad N, N, N^{\prime}, N^{\prime \prime}, N^{\prime \prime}$-pentamethyldiethylenetriamine or 3,3'-iminobis( $N, N$-dimethylpropylamine)] (1.0 eq.) was added and the mixture heated under reflux for 20-70 h. The reaction was monitored by TLC $\left(\mathrm{CHCl}_{3} / \mathrm{MeOH}, 10: 1\right)$. The precipitate formed was filtered off and crystallized from $\mathrm{CH}_{3} \mathrm{CN} / \mathrm{EtOH}$ (90:1) (compounds 4, 7, 10), or $\mathrm{CH}_{3} \mathrm{CN} / \mathrm{EtOH} / \mathrm{CHCl}_{3}$ $(5: 1: 1)$ (compounds $\mathbf{5}, \mathbf{6}, \mathbf{8}, \mathbf{9}, \mathbf{1 1}, \mathbf{1 2})$ to give white solids.

Trimethylene 1,3-bis( $N, N^{\prime}$-dimethyl- $N, N^{\prime}$-3 $\beta$-acetate-ergosta-5,7,22-triene)ammonium dibromide (4) white solid (80\%), m.p. $190-194{ }^{\circ} \mathrm{C} .{ }^{1} \mathrm{H}-\mathrm{NMR}$ : $\delta_{\mathrm{H}} 5.36$ (brs, 2H, 6-H), 5.30-5.17 (m, 6H, 7-H, 22-H,

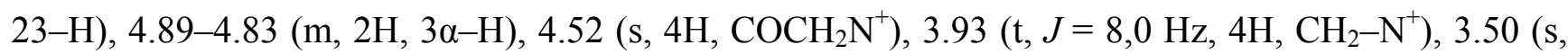
$\left.12 \mathrm{H}, \mathrm{N}^{+}\left(\mathrm{CH}_{3}\right)_{2}\right), 2.63\left(\mathrm{~d}, J=6.7 \mathrm{~Hz}, 2 \mathrm{H}, 5^{\prime}-\mathrm{CH}_{2}\right), 1.04\left(\mathrm{~d}, J=6.4 \mathrm{~Hz}, 6 \mathrm{H}, \mathrm{CH}_{3}-28\right), 1.01(\mathrm{~s}, 6 \mathrm{H}$, $\left.\mathrm{CH}_{3}-19\right), 0.93$ (d, $\left.J=6.4 \mathrm{~Hz}, 6 \mathrm{H}, \mathrm{CH}_{3}-21\right), 0.84$ (t, $J=6.1 \mathrm{~Hz}, 18 \mathrm{H}, \mathrm{CH}_{3}-18, \mathrm{CH}_{3}-26, \mathrm{CH}_{3}-27$ ). ${ }^{13} \mathrm{C}-\mathrm{NMR}: \delta_{\mathrm{C}} 163.70,150.47,139.75,135.33,132.02,123.26,118.08,76.77,62.71,62.07,56.95$, $51.58,44.67,42.72,40.71,38.78,36.73,36.57,36.31,34.86,33.72,32.97,27.32,26.30,24.99,21.70$, 20.87, 19.83, 19.51, 18.08, 17.52, 15.68. ESI-MS (m/z): $1085.48(100 \%)\left[\mathrm{C}_{67} \mathrm{H}_{108} \mathrm{~N}_{2} \mathrm{O}_{4}+\mathrm{Br}\right]^{+}, 502.79$ $(15 \%)\left[\mathrm{C}_{67} \mathrm{H}_{108} \mathrm{~N}_{2} \mathrm{O}_{4}\right]^{2+}$. FT-IR (KBr) $v_{\max }: 2,958,1,743,1,669,1,459,1,389,1,246,897$.

$N, N, N^{\prime}, N^{\prime}, N^{\prime \prime}$-pentamethyl-1,4,7-triazaheptane-1,7-bis( $N, N^{\prime}$-3 $\beta$-acetate-ergosta-5, 7,22-triene) ammonium dibromide (5) white solid (52\%), m.p. 194-195 ${ }^{\circ} \mathrm{C} .{ }^{1} \mathrm{H}-\mathrm{NMR}$ : $\delta_{\mathrm{H}} 5.35$ (brs, 2H, 6-H), 5.30-5.18 (m, $6 \mathrm{H}, 7-\mathrm{H}, 22-\mathrm{H}, 23-\mathrm{H}), 4.92-4.77(\mathrm{~m}, 2 \mathrm{H}, 3 \alpha-\mathrm{H}), 4.52\left(\mathrm{~s}, 4 \mathrm{H}, \mathrm{COCH}_{2} \mathrm{~N}^{+}\right), 4.01$ (brs, $4 \mathrm{H}, \mathrm{CH}_{2}-\mathrm{N}^{+}$), 3.49 (s, 12H, N $\left.{ }^{+}\left(\mathrm{CH}_{3}\right)_{2}\right), 3.12$ (brs, 4H, 5'- $\left.\mathrm{CH}_{2}\right), 2.38$ ( brs, 3H, $\left.\mathrm{NCH}_{3}\right), 1.04$ (d, $J=6.4 \mathrm{~Hz}, 6 \mathrm{H}$, $\left.\mathrm{CH}_{3}-28\right), 1.01$ (s, 6H, $\left.\mathrm{CH}_{3}-19\right), 0.93$ (d, $\left.J=6.4 \mathrm{~Hz}, 6 \mathrm{H}, \mathrm{CH}_{3}-21\right), 0.84$ (t, $J=6.1 \mathrm{~Hz}, 18 \mathrm{H}, \mathrm{CH}_{3}-18$, $\left.\mathrm{CH}_{3}-26, \mathrm{CH}_{3}-27\right) .{ }^{13} \mathrm{C}-\mathrm{NMR}: \delta_{\mathrm{C}} 163.89,150.45,139.73,135.30,131.98,123.21,118.02,76.56$, 61.91, 61.88, 56.92, 52.15, 50.59, 49.67, 44.63, 42.68, 40.66, 38.74, 36.69, 36.53, 36.28, 34.82, 33.69, 32.93, 27.28, 26.26, 24.95, 21.66, 20.81, 19.77, 19.45, 18.03, 17.47, 15.63. ESI-MS ( $\mathrm{m} / \mathrm{z}): 1128.55(35 \%)$ $\left[\mathrm{C}_{69} \mathrm{H}_{113} \mathrm{~N}_{3} \mathrm{O}_{4}+\mathrm{Br}\right]^{+}, 524.32(100 \%)\left[\mathrm{C}_{69} \mathrm{H}_{113} \mathrm{~N}_{3} \mathrm{O}_{4}\right]^{2+}$. FT-IR (KBr) $v_{\max }: 2,955,1,748,1,664,1,454$, $1,389,1,248,894$.

$N, N, N^{\prime}, N^{\prime}$-tetramethyl-1,5,9-triazanonane-1,9-bis ( $N, N$ '-3 $\beta$-acetate-ergosta-5, 7,22-triene) ammonium dibromide (6) white solid (93\%), m.p. 195-196 ${ }^{\circ} \mathrm{C} .{ }^{1} \mathrm{H}-\mathrm{NMR}: \delta_{\mathrm{H}} 5.35$ (brs, 2H, 6-H), 5.28-5.16

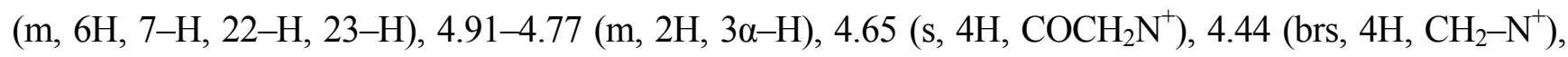
$3.58\left(\mathrm{~s}, 12 \mathrm{H}, \mathrm{N}^{+}\left(\mathrm{CH}_{3}\right)_{2}\right), 2.95$ (brs, 4H, 7'- $\left.\mathrm{CH}_{2}\right), 1.04$ (d, J =6.4 Hz, 6H, $\left.\mathrm{CH}_{3}-28\right), 1.00$ (s, 6H, $\left.\mathrm{CH}_{3}-19\right)$, $0.93\left(\mathrm{~d}, J=6.4 \mathrm{~Hz}, 6 \mathrm{H}, \mathrm{CH}_{3}-21\right), 0.84$ (t, $\left.J=6.1 \mathrm{~Hz}, 18 \mathrm{H}, \mathrm{CH}_{3}-18, \mathrm{CH}_{3}-26, \mathrm{CH}_{3}-27\right) .{ }^{13} \mathrm{C}-\mathrm{NMR}$ : $\delta_{\mathrm{C}} 164.07,150.55,139.87,135.42,132.07,123.30,118.11,76.55,65.61,61.62,57.01,51.34,50.82$, 
$44.74,42.78,40.78,38.85,36.81,36.65,36.46,36.39,34.93,33.83,33.04,27.83,27.43,26.45,26.39$, 25.13, 25.04, 21.77, 21.16, 20.96, 19.92, 19.60, 18.23, 17.62, 15.79. ESI-MS ( $\mathrm{m} / \mathrm{z}): 748.49(100 \%)$ $\left[\mathrm{C}_{70} \mathrm{H}_{115} \mathrm{~N}_{3} \mathrm{O}_{4}+2 \mathrm{Br}+\text { amine }+2 \mathrm{H}+\mathrm{AcOEt}\right]^{2+}, 530.94(70 \%)\left[\mathrm{C}_{70} \mathrm{H}_{115} \mathrm{~N}_{3} \mathrm{O}_{4}\right]^{2+}$. FT-IR (KBr) v $v_{\max }: 2,957$, $1,740,1,665,1,629,1,457,1,367,1,242,899$.

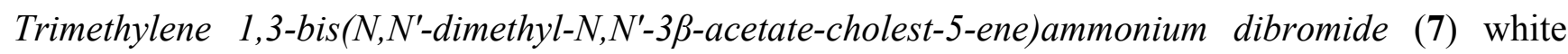

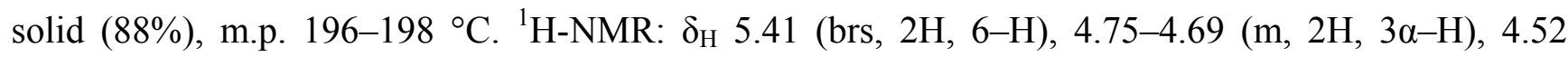
$\left(\mathrm{s}, 4 \mathrm{H}, \mathrm{COCH}_{2} \mathrm{~N}^{+}\right), 3.89\left(\mathrm{t}, J=6.6 \mathrm{~Hz}, 4 \mathrm{H}, \mathrm{CH}_{2}-\mathrm{N}^{+}\right), 3.47\left(\mathrm{~s}, 12 \mathrm{H}, \mathrm{N}^{+}\left(\mathrm{CH}_{3}\right)_{2}\right), 2.57-2.54(\mathrm{~m}, 2 \mathrm{H}$, $\left.5^{\prime}-\mathrm{CH}_{2}\right), 1.02\left(\mathrm{~s}, 6 \mathrm{H}, \mathrm{CH}_{3}-19\right), 0.92\left(\mathrm{~d}, J=6.4 \mathrm{~Hz}, 6 \mathrm{H}, \mathrm{CH}_{3}-21\right), 0.87$ (dd, $J=6.6,1.8 \mathrm{~Hz}, 12 \mathrm{H}$, $\left.\mathrm{CH}_{3}-26,27\right), 0.69$ (s, 6H, $\left.\mathrm{CH}_{3}-18\right) .{ }^{13} \mathrm{C}-\mathrm{NMR}: \delta_{\mathrm{C}} 163.57,138.56,123.37,77.19,62.07,61.66,56.51$, 55.97, 51.72, 49.83, 44.68, 42.13, 39.51, 39.31, 37.56, 36.65, 36.34, 35.99, 35.59, 31.71, 31.61, 28.01, 27.80, 27.33, 24.07, 23.64, 22.56, 22.30, 20.85, 18.99, 18.50, 11.65. ESI-MS ( $\mathrm{m} / \mathrm{z}): 1065.49(25 \%)$ $\left[\mathrm{C}_{65} \mathrm{H}_{112} \mathrm{~N}_{2} \mathrm{O}_{4}+\mathrm{Br}\right]^{+}, 492.79(100 \%)\left[\mathrm{C}_{65} \mathrm{H}_{112} \mathrm{~N}_{2} \mathrm{O}_{4}\right]^{2+}$. FT-IR (KBr) $v_{\max }: 2,953,1,737,1,665,1,462$, $1,385,1,240,886$.

$N, N, N^{\prime}, N^{\prime}, N^{\prime \prime}$-pentamethyl-1,4,7-triazaheptane-1,7-bis( $N, N^{\prime}$-3 $\beta$-acetate-cholest-5-ene) ammonium

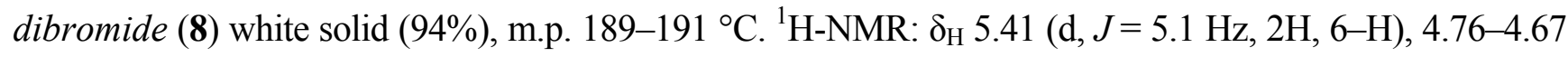
$(\mathrm{m}, 2 \mathrm{H}, 3 \alpha-\mathrm{H}), 4.48\left(\mathrm{~s}, 4 \mathrm{H}, \mathrm{COCH}_{2} \mathrm{~N}^{+}\right), 3.96\left(\mathrm{t}, J=6.4 \mathrm{~Hz}, 4 \mathrm{H}, \mathrm{CH}_{2}-\mathrm{N}^{+}\right), 3.46\left(\mathrm{~s}, 12 \mathrm{H}, \mathrm{N}^{+}\left(\mathrm{CH}_{3}\right)_{2}\right)$, $3.10\left(\mathrm{t}, J=6.6 \mathrm{~Hz}, 4 \mathrm{H}, 5^{\prime}-\mathrm{CH}_{2}\right), 2.35$ (brs, 3H, $\mathrm{NCH}_{3}$ ), 1.03 (s, 6H, $\left.\mathrm{CH}_{3}-19\right), 0.92$ (d, $J=6.5 \mathrm{~Hz}, 6 \mathrm{H}$, $\left.\mathrm{CH}_{3}-21\right), 0.87$ (dd, $\left.J=6.6,1.8 \mathrm{~Hz}, 12 \mathrm{H}, \mathrm{CH}_{3}-26, \mathrm{CH}_{3}-27\right), 0.69$ (s, 6H, $\left.\mathrm{CH}_{3}-18\right) .{ }^{13} \mathrm{C}-\mathrm{NMR}$ : $\delta_{\mathrm{C}} 163.75,138.55,138.55,76.67,61.54,61.52,56.49,55.96,52.18,50.63,49.82$ 42.13, 41.82, 39.51, $39.32,37.60,36.65,36.35,35.99,35.61,31.71,31.61,28.03,27.82,27.37,24.08,23.64,22.59,22.33$, 20.85, 19.01, 18.51, 11.66. ESI-MS (m/z): $1108.56(100 \%)\left[\mathrm{C}_{67} \mathrm{H}_{117} \mathrm{~N}_{3} \mathrm{O}_{4}+\mathrm{Br}\right]^{+}, 514.33(18 \%)$ $\left[\mathrm{C}_{67} \mathrm{H}_{117} \mathrm{~N}_{3} \mathrm{O}_{4}\right]^{2+}$. FT-IR (KBr) $v_{\max }: 2,954,1,739,1,663,1,464,1,387,1,238,884$.

$N, N, N, N^{\prime}, N^{\prime}$-tetramethyl-1,5,9-triazanonane-1,9-bis $\left(N, N^{\prime}\right.$-3 $\beta$-acetate-cholest-5-ene)ammonium dibromide (9) white solid (87\%), m.p. 200-201 ${ }^{\circ} \mathrm{C}$. ${ }^{1} \mathrm{H}-\mathrm{NMR}: \delta_{\mathrm{H}} 5.39$ (d, $\left.J=5.5 \mathrm{~Hz} 2 \mathrm{H}, 6-\mathrm{H}\right) 4.72-4.61(\mathrm{~m}, 2 \mathrm{H}$, $3 \alpha-\mathrm{H}), 4.58\left(\mathrm{~s}, 4 \mathrm{H}, \mathrm{COCH}_{2} \mathrm{~N}^{+}\right), 4.24\left(\mathrm{t}, J=9.4 \mathrm{~Hz}, 4 \mathrm{H}, \mathrm{CH}_{2}-\mathrm{N}^{+}\right), 3.51\left(\mathrm{~s}, 12 \mathrm{H}, \mathrm{N}^{+}\left(\mathrm{CH}_{3}\right)_{2}\right), 2.91$ (brs, $4 \mathrm{H}, 7$ - $\mathrm{CH}_{2}$ ), 1.01 (s, 6H, $\left.\mathrm{CH}_{3}-19\right), 0.92$ (d, $\left.J=6.4 \mathrm{~Hz}, 6 \mathrm{H}, \mathrm{CH}_{3}-21\right), 0.87$ (dd, $J=6.6,1.3 \mathrm{~Hz}, 12 \mathrm{H}$, $\left.\mathrm{CH}_{3}-26, \mathrm{CH}_{3}-27\right), 0.68\left(\mathrm{~s}, 6 \mathrm{H}, \mathrm{CH}_{3}-18\right) .{ }^{13} \mathrm{C}-\mathrm{NMR}: \delta_{\mathrm{C}} 163.95,138.74,123.38,77.13,65.59,61.58$, 56.60, 56.08, 50.81, 50.06, 48.91, 42.24, 39.43, 37.71, 36.75, 36.46, 36.11, 35.71, 31.83, 31.73, 28.14, 27.93, 27.47, 24.20, 23.77, 22.73, 22.47, 20.96, 19.15, 18.64, 11.77. ESI-MS (m/z): $732.01(100 \%)$ $\left[\mathrm{C}_{68} \mathrm{H}_{119} \mathrm{~N}_{3} \mathrm{O}_{4}+2 \mathrm{Br}+\text { amine }+2 \mathrm{H}+\mathrm{AcOEt}\right]^{2+}, 521.34(20 \%)\left[\mathrm{C}_{68} \mathrm{H}_{119} \mathrm{~N}_{3} \mathrm{O}_{4}\right]^{2+}$. FT-IR (KBr) $v_{\max }: 2,951$. $1,739,1,670,1,382,1,206,900$.

Trimethylene 1,3-bis ( $N, N^{\prime}$-dimethyl- $N, N^{\prime}$-3 $\beta$-acetate-5 $\beta$-cholestan)ammonium dibromide (10) white solid (82\%), m.p. $218-220{ }^{\circ} \mathrm{C} .{ }^{1} \mathrm{H}-\mathrm{NMR}: \delta_{\mathrm{H}} 4.88-4.80(\mathrm{~m}, 2 \mathrm{H}, 3 \alpha-\mathrm{H}), 4.51\left(\mathrm{~s}, 4 \mathrm{H}, \mathrm{COCH}_{2} \mathrm{~N}^{+}\right), 3.94$ $\left(\mathrm{t}, J=6.6 \mathrm{~Hz}, 4 \mathrm{H}, \mathrm{CH}_{2}-\mathrm{N}^{+}\right), 3.50\left(\mathrm{~s}, 12 \mathrm{H}, \mathrm{N}^{+}\left(\mathrm{CH}_{3}\right)_{2}\right), 2.64-2.61\left(\mathrm{~m}, 2 \mathrm{H}, 5{ }^{\prime}-\mathrm{CH}_{2}\right), 0.90(\mathrm{~d}, J=6.4 \mathrm{~Hz}$, $\left.6 \mathrm{H}, \mathrm{CH}_{3}-21\right), 0.86$ (dd, $\left.J=6.6,1.8 \mathrm{~Hz}, 12 \mathrm{H}, \mathrm{CH}_{3}-26, \mathrm{CH}_{3}-27\right), 0.83$ (s, 6H, $\left.\mathrm{CH}_{3}-19\right), 0.66$ (s, 6H, $\left.\mathrm{CH}_{3}-18\right) .{ }^{13} \mathrm{C}-\mathrm{NMR}: \delta_{\mathrm{C}} 163.59,77.15,62.24,56.23,56.11,54.00,51.49,44.49,42.40,39.77,39.32$, 36.45, 35.98, 35.62, 35.23, 33.48, 31.75, 28.36, 28.04, 27.82, 27.03, 24.00, 23.66, 22.57, 22.32, 21.04, 18.45, 11.96, 11.86. ESI-MS (m/z): $1069.53(10 \%)\left[\mathrm{C}_{65} \mathrm{H}_{116} \mathrm{~N}_{2} \mathrm{O}_{4}+\mathrm{Br}\right]^{+}, 494.81(100 \%)\left[\mathrm{C}_{65} \mathrm{H}_{116} \mathrm{~N}_{2} \mathrm{O}_{4}\right]^{2+}$. FT-IR (KBr) $v_{\max }: 2,934,1,735,1,464,1,381,1,245,893$. 
$N, N, N^{\prime}, N^{\prime}, N^{\prime \prime}$-pentamethyl-1,4,7-triazaheptane-1,7-bis( $N, N^{\prime}$-3 $\beta$-acetate-5 $\beta$-cholestan)ammonium dibromide (11) white solid (94\%), m.p. $198-201{ }^{\circ} \mathrm{C} .{ }^{1} \mathrm{H}-\mathrm{NMR}: \delta_{\mathrm{H}} 4.84-4.75(\mathrm{~m}, 2 \mathrm{H}, 3 \alpha-\mathrm{H}), 4.51\left(\mathrm{~s}, 4 \mathrm{H}, \mathrm{COCH}_{2} \mathrm{~N}^{+}\right)$, $4.05\left(\mathrm{t}, J=6.6 \mathrm{~Hz}, 4 \mathrm{H}, \mathrm{CH}_{2}-\mathrm{N}^{+}\right), 3.52\left(\mathrm{~s}, 12 \mathrm{H}, \mathrm{N}^{+}\left(\mathrm{CH}_{3}\right)_{2}\right), 3.13\left(\mathrm{t}, J=6.4 \mathrm{~Hz}, 4 \mathrm{H}, 5{ }^{\prime}-\mathrm{CH}_{2}\right), 2.38$ (brs, $\left.3 \mathrm{H}, \mathrm{NCH}_{3}\right), 0.90\left(\mathrm{~d}, J=6.5 \mathrm{~Hz}, 6 \mathrm{H}, \mathrm{CH}_{3}-21\right), 0.86\left(\mathrm{dd}, J=6.6,1.4 \mathrm{~Hz}, 12 \mathrm{H},\left(\mathrm{CH}_{3}-26, \mathrm{CH}_{3}-27\right), 0.82\right.$ (s, 6H, $\left.\mathrm{CH}_{3}-19\right), 0.65$ (s, 6H, $\left.\mathrm{CH}_{3}-18\right) .{ }^{13} \mathrm{C}-\mathrm{NMR}: \delta_{\mathrm{C}} 163.87,76.97,61.49,56.24,56.14,54.02,52.21$, 50.77, 49.88, 44.51, 42.43, 41.80, 39.79, 39.34, 36.48, 36.00, 35.65, 35.27, 33.54, 31.77, 28.40, 28.06, 27.84, 27.09, 24.02, 23. 70, 23.66, 22.58, 22.33, 21.07, 18.48, 11.99, 11.88. ESI-MS $(\mathrm{m} / \mathrm{z}): 1112.59$ $(15 \%)\left[\mathrm{C}_{67} \mathrm{H}_{121} \mathrm{~N}_{3} \mathrm{O}_{4}+\mathrm{Br}\right]^{+}, 516.34(100 \%)\left[\mathrm{C}_{67} \mathrm{H}_{121} \mathrm{~N}_{3} \mathrm{O}_{4}\right]^{2+}$. FT-IR (KBr) $v_{\max }: 2,935,1,743,1,465$, $1,379,1,246,895$.

$N, N, N$, $N$-tetramethyl-1,5,9-triazanonane-1,9-bis $\left(N, N^{\prime}\right.$-3 $\beta$-acetate-5 $\beta$-cholestan)ammonium dibromide (12) white solid (85\%), m.p. $206-207{ }^{\circ} \mathrm{C} .{ }^{1} \mathrm{H}-\mathrm{NMR}: \delta_{\mathrm{H}} 4.84-4.74(\mathrm{~m}, 2 \mathrm{H}, 3 \alpha-\mathrm{H}), 4.53\left(\mathrm{~s}, 4 \mathrm{H}, \mathrm{COCH}_{2} \mathrm{~N}^{+}\right.$), $4.23\left(\mathrm{t}, J=9.4 \mathrm{~Hz}, 4 \mathrm{H}, \mathrm{CH}_{2}-\mathrm{N}^{+}\right), 3.51\left(\mathrm{~s}, 12 \mathrm{H}, \mathrm{N}^{+}\left(\mathrm{CH}_{3}\right)_{2}\right), 2.90$ (brs, 4H, 7'- $\left.\mathrm{CH}_{2}\right), 0.90$ (d, $J=6.5 \mathrm{~Hz}$, $\left.6 \mathrm{H}, \mathrm{CH}_{3}-21\right), 0.86$ (dd, $\left.J=6.6,1.8 \mathrm{~Hz}, 12 \mathrm{H}, \mathrm{CH}_{3}-26, \mathrm{CH}_{3}-27\right), 0.82$ (s, 6H, $\left.\mathrm{CH}_{3}-19\right), 0.65$ (s, 6H, $\left.\mathrm{CH}_{3}-18\right) .{ }^{13} \mathrm{C}-\mathrm{NMR}: \delta_{\mathrm{C}} 163.99,77.20,65.58,61.59,56.31,56.20,54.07,50.82,44.58,42.50,39.87$, 39.42 , 36.65, 36.54, 36.08, 35.72, 35.37, 35.33, 34.12, 33.60, 31.90, 31.85, 28.45, 28.15, 27.92, 27.15, $24.11,23.77,22.72,22.47,21.13,18.58,12.12,11.98$. ESI-MS $(\mathrm{m} / z): 740.52(100 \%)\left[\mathrm{C}_{68} \mathrm{H}_{123} \mathrm{~N}_{3} \mathrm{O}_{4}+\right.$ $2 \mathrm{Br}+$ amine $+2 \mathrm{H}+\mathrm{AcOEt}]^{2+}, 523.36(25 \%)\left[\mathrm{C}_{68} \mathrm{H}_{123} \mathrm{~N}_{3} \mathrm{O}_{4}\right]^{2+}$. FT-IR $(\mathrm{KBr}) v_{\max }: 2,936,1,739,1,634$, $1,468,1,383,1,241,899$.

\section{Conclusions}

Nine new dimeric quaternary alkylammonium conjugates $\mathbf{4 - 1 2}$ of sterols $\mathbf{1}-\mathbf{3}$ were prepared by the reactions of ergosteryl $3 \beta$-bromoacetate, cholesteryl $3 \beta$-bromoacetate and dihydrocholesteryl $3 \beta$-bromoacetate with $N, N, N^{\prime}, N^{\prime}$-tetramethyl-1,3-propanediamine, $N, N, N^{\prime}, N^{\prime \prime}, N^{\prime \prime}$-pentamethyldiethylenetriamine and 3,3'-iminobis( $N, N$-dimethylpropylamine) in acetonitrile. These new compounds were characterized by spectroscopic and molecular structure methods. This study clearly shows that the conformation of investigated flexible molecules in solid and gas phase are a result of electrostatic interactions rather than hydrogen bonds. The obtained conjugates may find applications in molecular recognition and in pharmacology, especially as compounds with a high antimicrobial activity.

\section{Acknowledgments}

This work was supported by the funds from Adam Mickiewicz University, Faculty of Chemistry.

\section{Author Contributions}

The listed authors contributed to this work as described in the following. Bogumił Brycki gave the concepts of work, interpreted the results and prepared the manuscript. Hanna Koenig carried out of the synthetic work, interpreted the results and cooperated in the preparation of the manuscript. Iwona Kowalczyk performed FT-IR spectra. Tomasz Pospieszny performed semiempirical calculations and Prediction of Activity Spectra for Substances (PASS). All authors contributed with valuable discussions and scientific input and approved the final version. 


\section{Conflicts of Interest}

The authors declare no conflict of interest.

\section{References}

1. Nicolaou, K.C.; Montagnon, T. Molecules that Changed the World; WILEY-VCH Verlag GmbH \& Co. KGaA: Weinheim, Germany, 2008; pp. 79-90.

2. Dewick, P.M. Medicinal Natural Products A Biosynthetic Approach, 3rd ed.; John Wiley \& Sons, Ltd.: Chichester, UK, 2009; pp. 275-277.

3. Koskinen, A.M.P. Asymmetric Synthesis of Natural Products; John Wiley \& Sons, Ltd.: Chichester, UK, 2012; pp. 235-244.

4. Fieser, L.F.; Fieser M. Steroids; Reinhold Publishing Corporation: New York, NY, USA, 1959; pp. 53-90, 341-364.

5. Templeton, W. An Introduction to the Chemistry of Terpenoids and Steroids; Butterworths: London, UK, 1969; pp. 158-190.

6. Lednicer, D. Steroid Chemistry at a Glance; John Wiley \& Sons, Ltd.: Chichester, UK, 2011.

7. Parish, E.J.; Nes, W.D. Biochemistry and Function of Sterols; CRC-Press: Boca Raton, FL, USA, 1997.

8. Schaller, H. The role of sterols in plant growth and development. Prog. Lipid Res. 2003, 42, 163-175.

9. Jäpelt, R.B.; Jakobsem, J. Vitamin D in plants: A review of occurrence, analysis, and biosynthesis. Front. Plant. Sci. 2013, 4, 1-20.

10. Hanson, J.R. The Chemistry of Fungi; Royal Society of Chemistry: Cambridge, UK, 2008; pp. 1-18.

11. Vance, D.E.; van den Bosch, H. Cholesterol in the year 2000. Biochim. Biophys. Acta 2000, 1529, $1-8$.

12. Ikan, R. Natural Products a Laboratory Guide, 2nd ed.; Academic Press: London, UK, 1991; pp. 154-159.

13. Bloch, K. Sterol molecule: Structure, biosynthesis, and function. Steroids 1997, 57, 378-383.

14. Bloch, K. 50 Years ago, the structure of cholesterol and of the bile acids. Trends Biochem. Sci. 1982, 7, 334-336.

15. Murry, K.R.; Granner, D.K.; Mayes, P.A.; Rodwell, V.W. Harper's Biochemistry, 26th ed.; McGraw-Hill: New York, NY, USA, 1996; pp. 219-230.

16. Risley, J.M. Cholesterol biosynthesis: Lanosterol to cholesterol. J. Chem. Educ. 2002, 79, 377-384.

17. Hanukoglu, I. Steroidogenic enzymes: Structure, function, and role in regulation of steroid hormone biosynthesis. J. Steroid Biochem. Mol. Biol. 1992, 43, 779-804.

18. Nagrady, T.; Weaver, D.F. Medicinal Chemistry A Molecular and Biochemical Approach, 3rd ed.; Oxford University Press: New York, NY, USA, 2005; pp. 316-320.

19. Rosen, M.J.; Kunjappu, J.T. Surfactants and Interfacial Phenomena, 4th ed.; John Wiley \& Sons: Hoboken, NJ, USA, 2012; pp. 458-470, 502-529.

20. Zana, R.; Xia, J. Gemini Surfactants Synthesis, Interfacial and Solution-Phase Behavior, and Applications; Marcel Dekker: New York, NY, USA, 2004; pp. 1-5.

21. Menger, F.M.; Keiper, J.S. Gemini Surfactants. Angew. Chem. Int. Ed. 2000, 39, 1906-1920. 
22. Menger, F.M.; Littau, C.A. Gemini Surfactants: Synthesis and Properties. J. Am. Chem. Soc. 1991, 113, 1451-1452.

23. Hait, S.K.; Moulik, S.P. Gemini surfactants: A distinct class of self-assembling molecules. Curr. Sci. 2002, 82, 1101-1111.

24. Holmberg, K.; Jönsson, B.; Kronberg, B.; Lindman, B. Surfactants and Polymers in Aqueous Solution, 2nd ed.; John Wiley \& Sons: Chichester, UK, 2003; pp. 227-261.

25. Brycki, B. Gemini Alkylammonium Salts as Biodeterioration Inhibitors. Pol. J. Microbiol. 2010, 59, 227-231.

26. Pisárčik, M.; Devínsky, F.; Lacko, I. Critical micelle concentration, ionization degree and micellisation energy of cationic dimeric (gemini) surfactants in aqueous solution and in mixed micelles with anionic surfactant. Acta Facult. Pharm. Univ. Comen. 2003, 50, 119-131.

27. Kuperkar, K.; Modi, J.; Patel, K. Surface-Active Properties and Antimicrobial Study of Conventional Cationic and Synthesized Symmetrical Gemini Surfactants. J. Surfact. Deterg. 2012, 15, 107-115.

28. Shukla, D.; Tyagi, V.K. Cationic Gemini Surfactants: A Review. J. Oleo. Sci. 2006, 55, 381-390.

29. Para, G.; Hamerska-Dudra, A.; Wilk, K.A.; Warszyński, P. Surface activity of cationic surfactants, influence of molecular structure. Colloid Surf. A 2010, 365, 215-221.

30. Brycki, B.; Kowalczyk, I.; Koziróg, A. Synthesis, Molecular Structure, Spectral Properties and Antifungal Activity of Polymethylene- $\alpha, \omega$-bis $(N, N$-dimethyl- $N$-dodecyloammonium bromides $)$. Molecules 2011, 16, 319-335.

31. Ng, C.K.L.; Obando, D.; Widmer, F.; Wright, L.C.; Sorrell, T.C.; Jolliffe, K.A. Correlation of Antifungal Activity with Fungal Phospholipase Inhibition Using a Series of Bisquaternary Ammonium Salts. J. Med. Chem. 2006, 49, 811-816.

32. Laatiris, A.; El Achouri, M.; Infante, M.R.; Bensouda, Y. Antibacterial activity, structure and CMC relationships of alkanediyl $\alpha, \omega$-bis(dimethylammonium bromide) surfactants. Microbiol. Res. 2008, 163, 645-650.

33. Diz, M.; Manresa, A.; Pinazo, A.; Erra, P.; Infante, M.R. Synthesis, Surface Active Properties and Antimicrobial Activity of New Bis Quaternary Ammonium Compounds. J. Chem. Soc. Perkin. Trans. 1994, 2, 1871-1876.

34. Fraise, A.P.; Maillard, J.-Y.; Sattar, S.A. Russell, Hugo \& Ayliffe's Principles and Practice of Disinfection, Preservation \& Sterilization, 5th ed.; Wiley-Blackwell: Chichester, UK, 2013.

35. Walker, E.B. Quaternary Ammonium Compounds. In Handbook of Topical Antimicrobials Industrial Applications in Consumer Products and Pharmaceuticals; Paulson, D.S., Ed.; Marcel Dekker: New York, NY, USA, 2002; pp. 99-117.

36. Poroikov, V.V.; Druzhilovsky, D.; Vasilenko, V. Pharma Expert Predictive Services (C) 20112013, Version 2.0. Available online: http://www.pharmaexpert.ru/PASSOnline/ (accessed on 1 November 2013).

37. Poroikov, V.V.; Filimonov, D.A.; Borodina, Y.V.; Lagunin, A.A.; Kos, A. Robustness of biological activity spectra predicting by computer program PASS for noncongeneric sets of chemical compounds. J. Chem. Inf. Comput. Sci. 2000, 40, 1349-1355.

38. Poroikov, V.V.; Filimonov, D.A. How to acquire new biological activities in old compounds by computer prediction. J. Comput. Aided Mol. Des. 2002, 16, 819-824. 
39. Poroikov, V.V.; Filimonov, D.A. PASS: Prediction of Biological Activity Spectra for Substances. In Predictive Toxicology; Christopher, H., Ed.; Taylor and Francis: Boca Raton, FL, USA, 2005; pp. 459-478.

40. Stepanchikova, A.V.; Lagunin, A.A.; Filimonov, D.A.; Poroikov, V.V. Prediction of biological activity spectra for substances: Evaluation on the diverse sets of drug-like structures. Curr. Med. Chem. 2003, 10, 225-233.

41. Brycki, B.; Koenig, H.; Kowalczyk, I.; Pospieszny, T. Synthesis, spectroscopic and semiempirical studies of new quaternary alkylammonium conjugates of sterols. Molecules 2013, 18, 14961-14976.

42. Brycki, B.; Koenig, H.; Kowalczyk, I.; Pospieszny, T. Synthesis, spectroscopic and theoretical studies of new quaternary $\mathrm{N}, \mathrm{N}$-dimethyl-3-phtalimidopropylammonium conjugates of sterols and bile acids. Molecules 2014, 19, 4212-4233.

43. CAChe 5.04 User Guide; Fujitsu: Chiba, Japan, 2003.

44. Stewart, J.J.P. Optimization of parameters for semiempirical methods. III Extension of PM3 to $\mathrm{Be}, \mathrm{Mg}, \mathrm{Zn}, \mathrm{Ga}, \mathrm{Ge}, \mathrm{As}, \mathrm{Se}, \mathrm{Cd}, \mathrm{In}, \mathrm{Sn}, \mathrm{Sb}, \mathrm{Te}, \mathrm{Hg}, \mathrm{Tl}, \mathrm{Pb}$, and Bi. J. Comput. Chem. 1991, 12, 320-341.

45. Stewart, J.J.P. Optimization of parameters for semiempirical methods I. Method. J. Comput. Chem. 1989, 10, 209-220.

Sample Availability: Samples of the compounds 4-12 are available from the authors.

(C) 2014 by the authors; licensee MDPI, Basel, Switzerland. This article is an open access article distributed under the terms and conditions of the Creative Commons Attribution license (http://creativecommons.org/licenses/by/3.0/). 